\title{
The prehistoric exploitation of salt in Europe
}

\author{
Anthony HARDING ${ }^{1, *}$ \\ 1 University of Exeter, Department of Archaeology, Laver Building, North Park Road, Exeter, EX4 4QE, UK
}

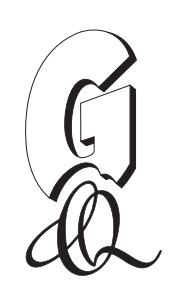

Harding, A., 2014. The prehistoric exploitation of salt in Europe. Geological Quarterly, 58 (3): 591-596, doi: 10.7306/gq.1164

The article considers the nature and extent of salt production in prehistoric Europe, in the light of recent fieldwork. The biological needs of humans and animals are described, as this might have determined the extent to which ancient communities sought out salt if they did not have access to it locally. Three main zones of production, utilising solar evaporation, briquetage, and a technique involving wooden troughs, are described; deep mining seems only to have occurred in the Austrian Alps. Lastly consideration is given to the effects of salt production within and between communities, bearing in mind the widely expressed view that in prehistory richness in salt led to richness in other goods.

Key words: salt, prehistoric Europe, biological need for salt, production techniques.

INTRODUCTION

Salt (common salt, sodium chloride) is generally recognised to have been an important, possibly a crucial, commodity in ancient times, as in modern. It is well-known that a certain intake of salt is required for human health, and also for animal health. It is also used today in a range of industrial applications, and in traditional societies for the preservation of food, for its curative properties, and for activities such as tanning. Historically and ethnographically, it also has a symbolic value in many contexts. Archaeologically speaking, the study of salt is complicated, however, because the salt itself almost never survives; it is the evidence for its production (and perhaps its movement in trade) that is found in archaeological contexts. This may take various forms, and the study of these surviving remains is usually a technological matter. Equally important for our understanding of the ancient economy is the study of its social and economic context, which is a much more difficult undertaking.

In this article I present some recent evidence for particular technologies that were in use in the eastern half of Europe, mainly in the Bronze Age (third and second millennia BC), and add some comments on their implications for the scale and impact of production in the areas concerned. The detailed evidence has already been published (Harding and Kavruk, 2013), while a more general recent consideration of ancient European salt production and its implications is also available (Harding, 2013). It is therefore not necessary to repeat much of the detailed material that was presented in those publications; instead, I will focus on issues of more general application.

\section{*E-mail: a.f.harding@exeter.ac.uk}

Received: Received: March 10, 2014; accepted: April, 10, 2014; first published online: April 14, 2014
Opinions differ about exactly how much salt is required by humans and animals, and the extent to which it needs to be added to food to satisfy biological needs; and therefore how far people needed to import it from outside their home area. In the literature prior to recent years it is commonly stated that $6 \mathrm{~g}$ of salt are needed per adult per day, but in recent times as little as $1.5 \mathrm{~g}$ is suggested to be an acceptable minimum (Cappuccio and Capewell, 2010). That is a rather small amount, which could be acquired through a diet involving the consumption of meat and related substances; though the required amount does also depend on climate, energy expenditure, and lifestyle. Blood is an especially good source of sodium. The extent to which salt would need to be provided for animals in areas without halophyte vegetation is more uncertain (most recently Jiménez Guijarro, 2011). The conclusion is that humans usually get the salt they need for health from their diet, provided that they are meat-eaters. A vegetarian diet makes it much harder to survive, since grains, pulses and nuts are poor in sodium. Since animal bones are so commonly found on archaeological sites, it is likely that elective vegetarianism was uncommon in ancient times.

\section{SALT IN EUROPE}

Salt (halite) deposits are common in Europe (Fig. 1). Most countries have at least some access to salt; if not in rock form then in brine form (sea water or brine springs). Romania, Poland and Germany are especially rich in salt deposits, but many other countries have deposits that are adequate for modern needs. It is tempting to think of the ancient past in terms of the borders of modern countries, but that is very misleading. Such a process disguises the fact that substantial parts of present-day countries have no salt at all. The most notable of these cases is Hungary, but in some other countries salt is very restricted in occurrence - for instance Ireland, where a mine on the north coast at Kilroot is the only one in the country. Even France, 


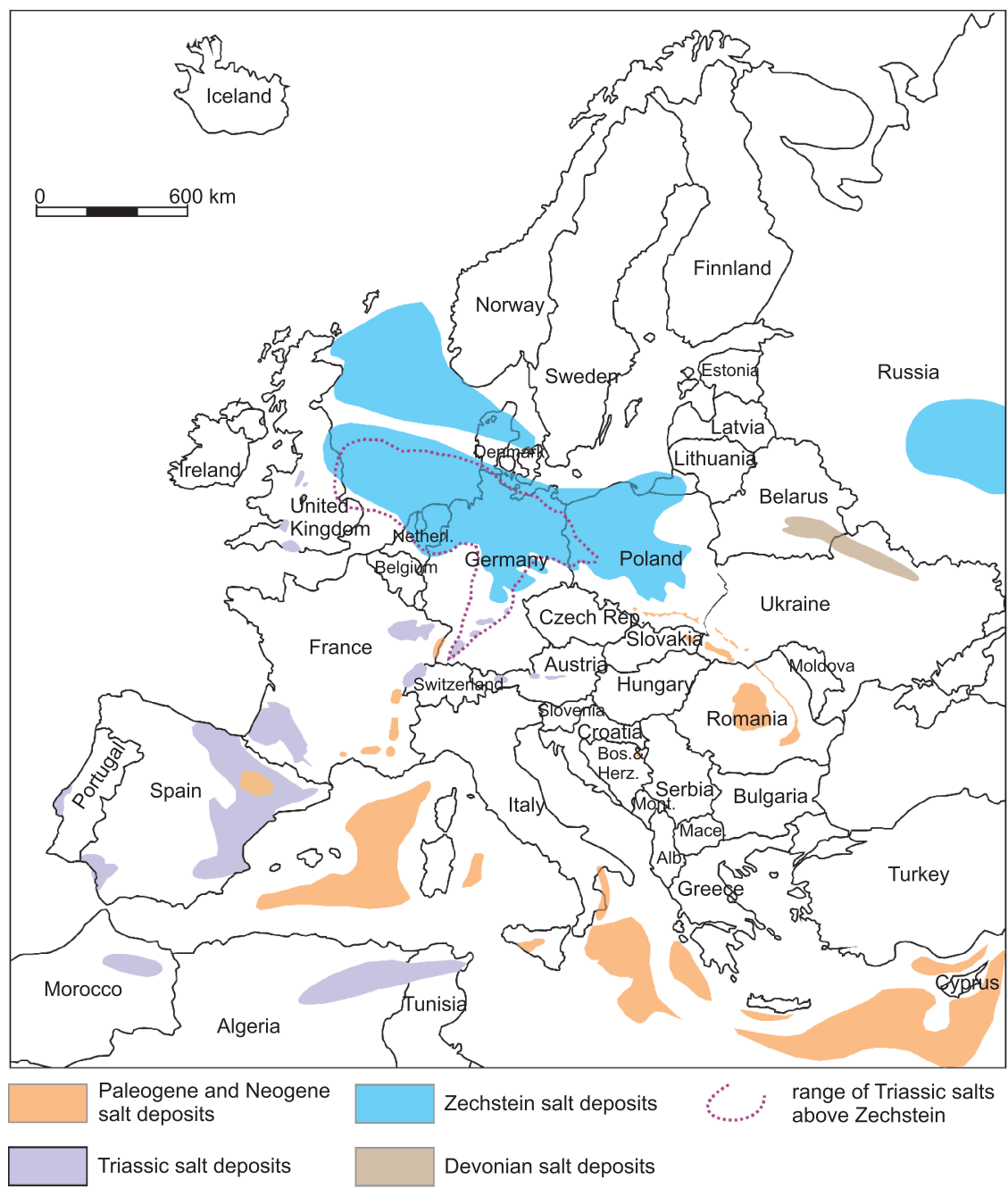

Fig. 1. The major salt deposits of Europe

which has plentiful deposits in the east, and abundant sea salt production on the Atlantic coast, has large areas without immediate access to salt; Ukraine is another case, where many deposits in the extreme west and large mines in the east are separated by a vast distance without any sources.

Archaeologically, it is relatively easy to look at major outcrops of rock salt and compare their location with that of findspots of various ages. It is less easy to map inland brine springs, and harder still to detect coastal exploitation from ancient times. Nevertheless, all these have successfully been achieved. Thus there is abundant archaeological evidence for prehistoric salt exploitation in Austria, parts of eastern France and various parts of Germany, also for Britain, Romania and (to some extent) Poland. The question that arises is, which sources did the areas without such evidence tap to get such salt as they needed? Even if biological reasons did not require such procurement, other reasons (as outlined above) did. For archaeologists, identifying the salt source which supplied particular regions becomes one of the major tasks in the understanding of ancient trade and exchange. Unfortunately, no method has yet been devised for uniquely identifying particular sources by chemical means, in spite of various attempts. The chlorine is too abundant and too soluble for any of the simpler methods to work, and there are geological reasons why it will not be appro- priate to use chlorine isotopes (all the deposits near the earth's crust are dominated by sea water and the resulting evaporites, so will have similar values). Comparable observations were made following analyses by Bukowski in the Kraków area (Bukowski, 2003). If this is confirmed by new work, it means that archaeological inferences will represent the main, perhaps the only, way forward.

\section{THE MAIN METHODS OF ANCIENT SALT PRODUCTION}

In ancient times salt was produced in a number of different ways. The two best known of these are mining and evaporation of salt water (brine). Mining, in the sense of digging shafts or adits deep into the ground, is only known for certain at the great Austrian sites of Hallstatt and the Dürrnberg near Hallein in Salzburg province, but quarrying (the extraction of hard rock where it outcrops on the earth's surface, in other words a variant of mining) must also have been extensively practised. Rock salt is most obviously salt in crystalline form, but it requires grinding before it can be eaten, and only the purest deposits would be suitable for human consumption.

Evaporation of brine or sea water could be carried out in a number of ways. The most obvious, solar evaporation in salt lagoons, is still practised in Mediterranean countries today and involves little or no special technology, though it is hard to spot archaeologically. The best known archaeological source involves briquetage (the coarse ceramic used for brine boiling, referring either to elements of the furnace itself or to the pedestals that supported the evaporation trays and to the containers that held the brine; Fig. 2). This material has been known for centuries, first being identified and named in the 18th century at the great salt production sites of the Seille valley in eastern France. It is best known in Iron Age contexts, but it started in the Neolithic in eastern Romania, and was used in various parts of Europe in the Bronze Age (Germany, Britain, Poland). By the Iron Age, huge quantities of briquetage were being produced in some areas, most notably the Seille valley in Lorraine, where Marsal, Moyenvic and other places were prolific production centres; this is also the time when production around North Sea and Atlantic coasts was abundant.

A function as evaporation vessels has been suggested for apparently domestic pottery in a number of situations, starting with Chalcolithic Bulgaria and suggested for some other places, including the Wieliczka area of Little Poland. Without effective analysis of the surface or interior of the pottery it is hard to be sure about this, but certainly at Provadia in Bulgaria quantities of ceramic beside the salt source are so vast that no other explanation seems possible. In other cases one can point to sites on or beside salt sources without obvious briquetage; in such 


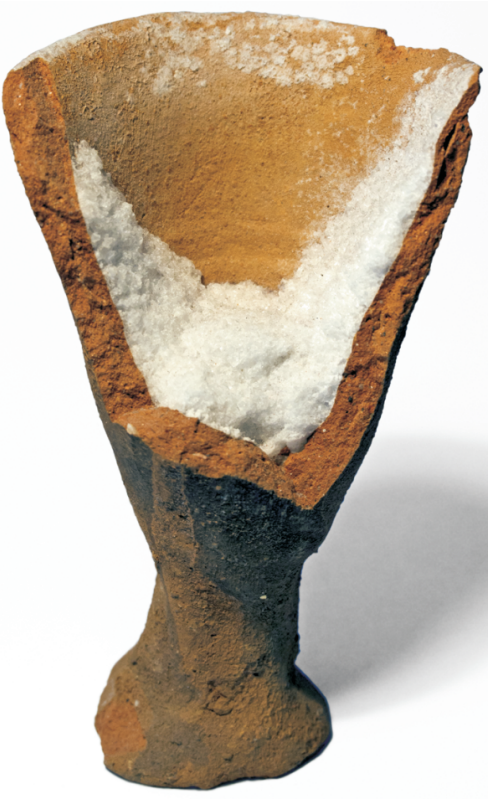

Fig. 2. Briquetage vessel containing salt crystals (reconstructed vessel by J. Fraś)

Photo: S. Goddard

instances it may be reasonable to suppose that ordinary domestic pottery was used for the purpose.

Related techniques involve throwing brine onto bonfires and collecting up the crystals as they form, or burning halophyte vegetation. Both of these methods, well-attested ethnographically, may have been used in ancient times but will be hard to spot archaeologically.

The last technique to be introduced here is what we may call the trough technique. This is only found (so far) in a restricted geographical area in eastern Europe. It is not yet fully understood, but seems to have involved the extraction of rock salt from surface quarries or shafts several metres deep, and probably also the manipulation of brine.

\section{THE TROUGH TECHNIQUE IN EASTERN EUROPE}

What I am calling the trough technique was first discovered in the early 19th century in the salt mining district of what was then northeastern Hungary, nowadays the Transcarpathian region of Ukraine, centred on modern Solotvyno (Harding and Kavruk, 2013: 194-198). Another discovery was made in the 1930s at Valea Florilor near Turda in Transylvania. It was only with recent discoveries in Transylvania, however, that the form of the objects could be identified with certainty, and methods of utilisation suggested. Radiocarbon dates indicate that all troughs dated so far originated in the Bronze Age, and may have continued in use into the Iron Age, or even later.

The troughs consist of hollowed out tree trunks, enclosed at one end (or possibly in some cases both ends), 1.5 to $3 \mathrm{~m}$ in length, with a row of holes perforated in the base, the holes filled with wooden pegs that were themselves perforated (Fig. 3). These latter perforations were filled with twisted cord or wooden pins. At least fourteen of these objects have now been found, on six sites, all but one of them in Romania; only one, however, has been the subject of proper archaeological investigation, Băile Figa (Figa Spa) near Beclean in northern Transylvania. Here, excavation since 2007 has uncovered a number of these troughs, most of them fragmentary but also showing important evidence for how they might have been used. Two particularly relevant observations may be made: first, excavation in the southern part of the site produced evidence for the mounting of troughs on a stand of wooden poles, suggesting that they were raised above the level of the working surface (wherever that might have been in relation to the rock salt); second, in the central part of the site, where the first trough was originally noted in 1982 , no less than four troughs were present, lying more or less in a line. This suggests that they worked together, and probably in sequence rather than in parallel, the product of one feeding into the next - whatever that product may have been.

This raises the interesting but tricky question of how the troughs functioned. Obviously liquid of some sort was intended to percolate through the perforations in the trough base. When the very first trough, from a site in present-day Ukraine, was published (Preisig, 1877), the suggestion was that water would be introduced into the trough and allowed to drip onto the surface of salt rock - indeed, the same find included a block of rock salt with conical depressions in its upper surface, believed to result from such an activity. Recent experiments conducted at the Figa site have confirmed the validity of this reconstruction (Buzea, 2010). Fresh water was channeled into a replica trough
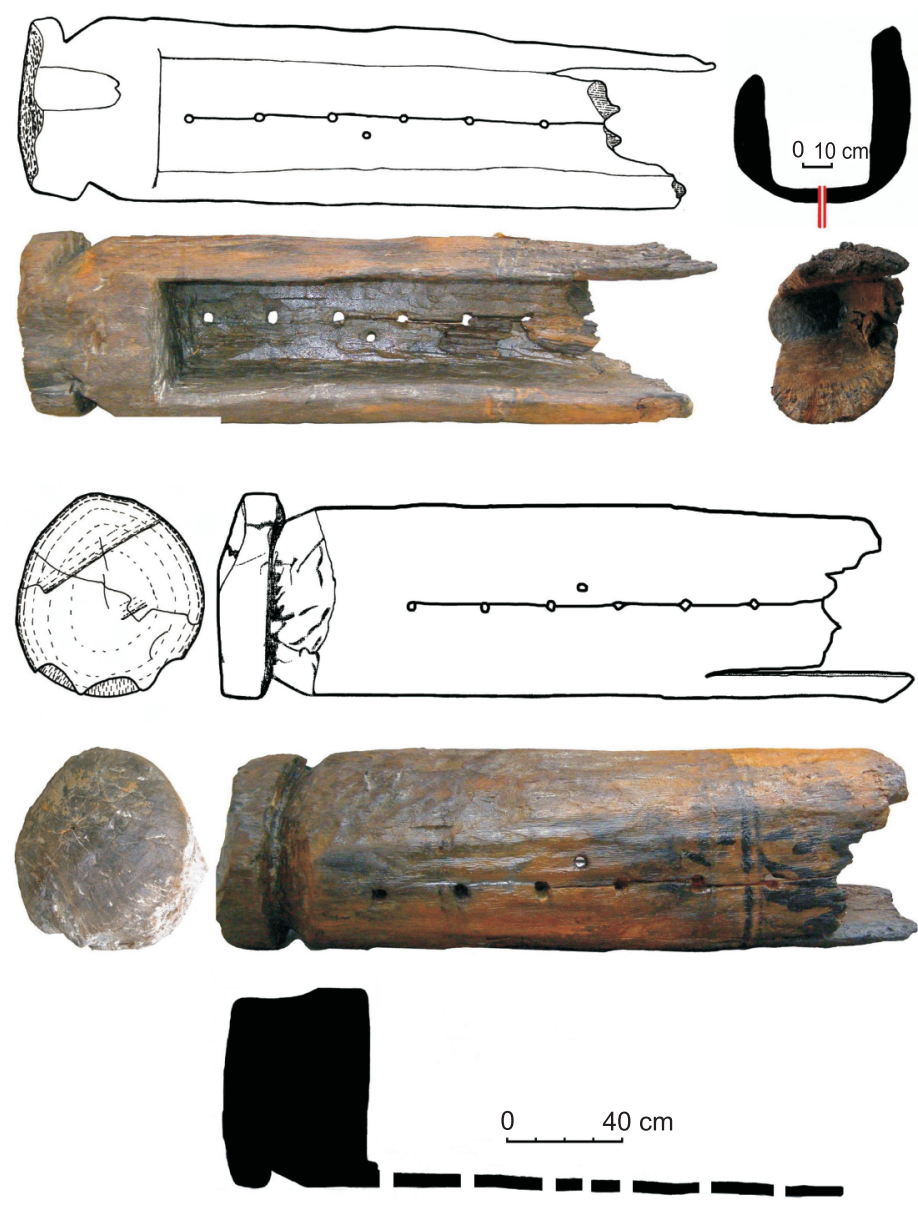

Fig. 3. Trough recovered in a salt production site at Băile Figa, near Beclean, Romania 
and allowed to drip onto a rock salt surface. Within a few hours, significant depressions were created; hammering wooden wedges into these depressions allowed chunks of rock to be broken off. This is especially important given that removing such chunks manually by hammering is extremely arduous.

On the other hand, such a procedure need not involve the use of more than one trough at a time: doing so increases quantity but not quality. This might suggest that another function was possible: the concentration of brine in order that salt crystals could be obtained more easily, whether within the troughs themselves or forming on or in some container or material beneath the troughs. No full-scale experiment has yet been conducted to demonstrate whether this is possible, but a small reconstruction has been attempted, which appears to show that the idea has some validity (Harding, 2009). If this technique were to be successful, it might be possible to imagine a sequence of troughs, one carrying brine into the next, the brine becoming more concentrated with each successive stage.

Kavruk and I have argued that this technology, whatever its precise nature, would have enabled rather large quantities of salt to be produced: much more than was possible by the briquetage technique, at least in chronological contexts prior to the Iron Age. While it is impossible to estimate actual quantities, the impression given is that the production can be called "industrial" in scale. That means that the salt produced was intended not just for consumption at home, in a domestic context, but for movement in exchange to communities removed from the place of production, perhaps significantly removed. This is something which otherwise has been considered a feature of Iron Age production, notably in the Seille valley in Lorraine, where huge quantities of briquetage have been found over many years (recent review: Olivier and Kovacik, 2006). If these notions are correct, we can take such massive production back one thousand years, to the Middle and Late Bronze Age.

\section{THE ZONES OF SALT PRODUCTION}

Salt production in Europe in later prehistory can now be seen to fall into a number of production zones, in each of which a different technology predominated. Around Mediterranean shores, solar evaporation was the normal technique, using mainly coastal lagoons. This is essentially what the Roman geographer Pliny tells us of ancient Rome, referring specifically to Sicily and elsewhere (Natural History XXXI, 73); for Rome itself the coast between Ostia and Tarquinia was one of the premier production areas. Most ancient authors evidently took such production as so obvious that they say little about it; one can assume that it occurred widely, however, from the fact that it is widely present today. It is a technology that involves almost no special equipment, just a suitable area beside the sea (or other salt water source) where the action of the sun would produce salt crystals naturally.

It has been suggested that solar evaporation might have taken place around other seas, such as the Baltic (Jaanusson and Jaanusson, 1988), or the Black Sea (Ivanova, 2010), but without additional input from artificial heat sources this seems questionable.

Across most of northern Europe, the production technique that was in common use was the briquetage technique, at least in the Bronze and Iron Ages. Huge quantities of ceramic emanating from salt boiling are present in parts of France - not only Lorraine, but also Atlantic coasts; and this was the technology that formed the "Red Hills" of eastern England, using sea water (Fawn et al., 1990; Daire, 1994, 2003; Hocquet, 2001; Kinory, 2012). It is known too from Germany and the Low Countries in the Iron Age, and while the number of Bronze Age briquetage sites is much lower, and the quantities much smaller, it was this technology that was in use in western Europe in the Bronze Age as well - the sites around Halle on the Saale being the best known (Matthias, 1961, 1976; Riehm, 1962), but there are increasing numbers of finds in eastern Germany and Poland (Kadrow, 2003; Kadrow and Nowak-Włodarczak, 2003; Jockenhövel, 2012). In the Iron Age the quantities of salt produced must have been very considerable, at least in the Seille valley; in the Bronze Age, on the other hand, the volume cannot have been very large since any one container only produced $100-150 \mathrm{~g}$ of salt. I shall return to the implications of this below.

The third production zone was that where the trough technique, as described above, was in place. At present this technology is only known from the Carpathian Basin, and specifically Transylvania and the Transcarpathian Ukraine, but it seems unlikely that such a developed set of techniques would have been so restricted geographically if, as we believe, it was a highly effective means of producing salt. It is also currently known only from the Bronze Age - or to be more precise, all the troughs currently dated were from trees felled in the Bronze Age. At Băile Figa the timbers and bindings supporting one of the troughs actually date to the early medieval period, even though the trough itself was of Bronze Age date. In other words, even if no troughs were being fashioned after the Late Bronze Age, it is possible that they were reused, using the same or similar technology, centuries later.

These three production zones (Fig. 4) account for a large proportion of the salt produced in prehistoric Europe. I have not included the mines of Austria as a "zone" because their home is limited to one part of the eastern Alps, though this might disguise an importance in trade and exchange that was out of all proportion to their geographical limits.

\section{THE IMPLICATIONS FOR THE ANCIENT ECONOMY AND ANCIENT SOCIETY}

It remains to consider what effect the production of salt had on the society or societies that were involved in the production. In particular it is important to know what the scale of production was, and who carried it out. Was this a small-scale operation, designed to meet local domestic needs? Or was it a big affair, producing large quantities (many kilos) of salt, more than would be needed locally and therefore intended to be moved to other communities, near and far, in exchange? Or something in between?

It is hard to answer these questions in the absence of more information on the populations undertaking the production, along with their places of residence, the artefacts they used, and their burials. Unfortunately these are issues which are extremely hard to address, not least because salt does not survive in the archaeological record, even in small traces (which might have indicated which artefacts were associated with the movement of salt, for instance). In general, one may suppose that where a settlement site is right beside a salt source, then there was a direct connection between the two; such a case is that of Lunca-Poiana Slatinei in Moldavia, where a small Neolithic tell lies immediately beside a brine well (Weller et al., 2009), or Provadia (Mirovo) in Bulgaria, where a similar situation obtains (Nikolov, 2012). Even in these instances, however, one can only speculate how many individuals took part in the operation, and for whom the product was intended. A great production site such as those at Marsal or Moyenvic must have utilised the skills and time of many people - scores or even hundreds, to judge from the massive extent of the debris created. On the other hand, most of the briquetage sites round Halle, or on the east coast of England, need only have required a few dozen people, at most. 


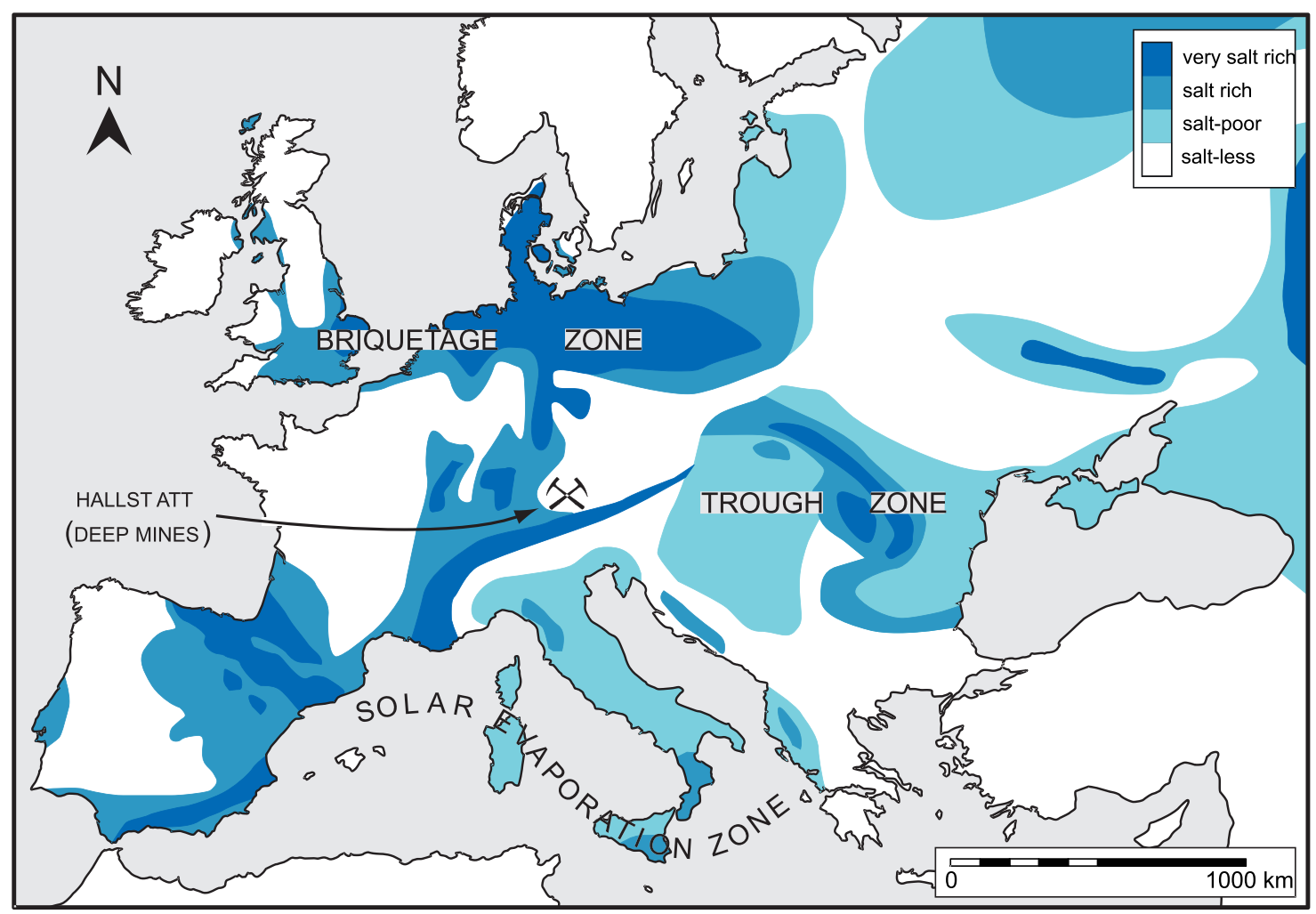

Fig. 4. The salt production zones of Bronze-Iron Age Europe

There has also been speculation as to whether men or women, or both, undertook the labour involved. In part one can approach this topic simply through a consideration of the physical strength which would be needed to carry out the work. For the briquetage and solar evaporation techniques, there seems no particular reason why both sexes should not have been involved. While felling trees and transporting them to the site might have been male work, the production of briquetage, the building of the furnaces, and the boiling of the brine do not seem to involve particular strength. Mining and quarrying, on the other hand, is extremely hard work and might have necessitated male strength.

One recent examination was of the bones of individuals buried in the cemetery at Hallstatt (Pany and Teschler-Nicola, 2007), which found that females as well as males had well-developed muscle attachments for flexing the elbow (involved in hammering) and for lifting and carrying heavy loads. In that case, therefore, it seems that women and men in the local population (who had traditionally been considered an elite group) were involved in the production of salt. In other areas there is only circumstantial evidence to go on. For instance, at the site of Marsal "la Digue" in the Seille valley, finds of schist and lignite rings were probably part of female dress attire and indicate the presence of women in the work force involved in production (Olivier, 2010).

The wider question, however, relates to the organisation of production. Here the Romanian sites allow speculation on a more informed basis. Wood-cutters and carpenters led the way, to select timber and fashion the troughs and other installations (the troughs were the only massive items, requiring an input of time that one may put at days rather than hours). Even at the workface, carpenters were crucial, positioning the troughs on stands, fashioning and positioning channelled pieces, and building storage tanks of wattle or plank. Salt workers must have been responsible for testing the salinity of brine in tanks and determining when it was suitable for the final stage, producing salt crystals and cakes. There must have been a sizeable support force of victuallers, transporters, and other workers. Especially if, as suggested above, the troughs worked in sequence, this was a very substantial undertaking, producing relatively large quantities of salt. It seems very possible that the community undertaking this work was engaged in it for most of the snow-free year - say nine months. Of course it is also possible that the operation was conducted by part-time specialists, who also possessed animals and small-holdings in the vicinity.

It has often been supposed that the production and control of salt was what led to the richness of the graves in the cemetery at Hallstatt and other locations in this part of Austria. By the same token, Romanian scholars have tended to assume that the massive hoards of bronze found in parts of Transylvania in the Bronze Age represented the wealth acquired by communities controlling the production and trade of salt. I have considered these arguments in detail elsewhere (Harding, 2013); here I will only remark that assuming a connection of this kind brings with it a presumption that modern ideas of value also obtained in prehistory, that there was some kind of mechanism by which wealth in one commodity could be transferred to another, and that bronze wealth could somehow be shared among the community as a result of the movement of an entirely different commodity. All these are assumptions which are impossible to prove, and in some instances seem rather unlikely.

Nonetheless, it is clear that some of the production of salt in European prehistory was on a scale that dwarfs what individual households or communities would require. It must therefore have been intended for other people, in other words by trade or exchange. Seen in this light, one can certainly believe that the production of salt was an industry not much less important than that involving metal ores. 


\section{CONCLUSION}

While no one can doubt that salt was a commodity of high importance in European prehistory, its significance as a substance of economic value probably varied from area to area and period to period. Especially in the Carpathian region the rich deposits of salt were intensively utilised from the Bronze Age on, with some evidence for preceding Neolithic exploitation. While we await the development of an analytical method which would enable us to detect the presence of salt from specific sources both near to and far from its origin, much can be achieved through archaeological methods involving surface survey and, in certain situations, excavation. It was little more than a lucky chance that the extraordinary wooden installations of Băile Figa were recognised for what they were and investigated before the area was developed; such surface prospection has yet to be conducted by archaeologists in other areas where similar geological conditions obtain.

Given the range of techniques now available for archaeological study, and for experimental reconstruction of the ancient processes of salt production, it is entirely possible that accurate estimates of production in specific places at specific times will become feasible. If that can be achieved, our understanding of the position of salt in the prehistoric economy will be put on a level that otherwise only applies in historic periods.

Acknowledgments. Helpful comments and suggestions from T. Peryt, K. Bukowski, V. Kavruk and an anonymous referee are gratefully acknowledged.

\section{REFERENCES}

Bukowski, K., 2003. Określenie warunków geologicznych ze szczególnym uwzględieniem możliwości występowania słonych żródeł dla rejonu stanowiska nr 27 Kraków-Bieżanów (in Polish). In: Kraków-Bieżanów, stanowisko 27 i Kraków-Rzaka, stanowisko 1 , osada kultury łużyckiej (ed. S. Kadrow): 273-284. Zespół do Badań Autostrad. Via Archaeologica. Źródła z badań wykopaliskowych na trasie autostrady A4 w Małopolsce, Kraków.

Buzea, D., 2010. Experimentul "Troaca". Angustia, 14: 245-256.

Cappuccio, F., Capewell, S., 2010. A sprinkling of doubt. New Scientist, 1 May 2010: 22-23.

Daire, M.-Y., 1994. Le sel gaulois. Bouilleurs de sel et ateliers de briquetages armoricains à l'Âge du Fer. Centre Régional d'Archéologie d'Alet, Saint-Malo.

Daire, M.-Y., 2003. Le sel des Gaulois. Éditions Errance, Paris.

Fawn, A.J., Evans, K.A., McMaster, I., Davies, G.M.R., eds., 1990. The Red Hills of Essex: Salt-making in Antiquity. Colchester Archaeological Group, Colchester.

Harding, A., 2009. Producing salt in wooden troughs: the technology of Bronze Age salt production in Transylvania. In: In medias res praehistoriae. Miscellanea in honorem annos LXV peragentis Professoris Dan Monah oblata (ed. G. Bodi): 195-204. Editura Universitații "Alexandru loan Cuza", laşi.

Harding, A., 2013. Salt in Prehistoric Europe. Sidestone Press, Leiden.

Harding, A., Kavruk, V., 2013. Explorations in Salt Archaeology in the Carpathian Zone. Archaeolingua, Budapest.

Hocquet, J.-C., 2001. Hommes et Paysages du Sel. Une aventure millénaire. Actes Sud, Arles.

Ivanova, S.V., 2010. Prirodnye resursi i ekonomika drevnikh obshchestv. Stratum Plus, 2: 49-97.

Jaanusson, H., Jaanusson, V., 1988. Sea-salt as a commodity of barter in Bronze Age trade of northern Europe. In: Trade and Exchange in Prehistory. Studies in Honour of Berta Stjernquist (eds. B. Hardh, L. Larsson, D. Olausson and R. Petré): 107-12. Historiska Museum, Lund.

Jiménez Guijarro, J., 2011. The beginning of the salt exploitation in Spain: thinking about the salt exploitation in the Iberian peninsula during prehistoric times. In: Archaeology and Anthropology of Salt: a Diachronic Approach (eds. M. Alexianu, O. Weller and R.-G. Curcă): 123-133. Archaeopress, Oxford. BAR International Series 2198.

Jockenhövel, A., 2012. Bronzezeitliche Sole in Mitteldeutschland: Gewinnung - Distribution - Symbolik. In: Salt and gold: the role of salt in prehistoric Europe (eds. V. Nikolov and K. Bacvarov): 239-257. Verlag Faber, Provadia/Veliko Tarnovo.

Kadrow, S. 2003. Charakterystyka technologiczna ceramiki kultury łużyckiej (in Polish). In: Kraków-Bieżanów, stanowisko 27 i Kraków-Rząka, stanowisko 1, osada kultury łużyckiej (ed. S. Kadrow): 205-220. Zespół do Badań Autostrad. Via Archaeologica. Źródła z badań wykopaliskowych na trasie autostrady A4 w Małopolsce, Kraków.

Kadrow, S., Nowak-Włodarczak, E., 2003. Osada kultury łużyckiej na stan. 27 w Krakowie-Bieżanowie - organizacja warzelnictwa soli (in Polish). In: Epoka brazu i wczesna epoka żelaza w Karpatach polskich (ed. J. Gancarski): 549-567. Muzeum Podkarpackie w Krośnie, Krosno.

Kinory, J., 2012. Salt Production, Distribution and Use in the British Iron Age. Archaeopress, Oxford

Matthias, W., 1961. Das mitteldeutsche Briquetage - Formen, Verbreitung und Verwendung. Jahresschrift für mitteldeutsche Vorgeschichte, 45: 119-225.

Matthias, W., 1976. Die Salzproduktion - ein bedeutender Faktor in der Wirtschaft der frühbronzezeitlichen Bevölkerung an der mittleren Saale. Jahresschrift für mitteldeutsche Vorgeschichte, 60: 373-94

Nikolov, V., 2012. Salt, early complex society, urbanization: Provadia-Solnitsata (5500-4200 BC). In: Salt and gold: the role of salt in prehistoric Europe (eds. V. Nikolov and K. Bacvarov): 11-65. Verlag Faber, Provadia/Veliko Tarnovo.

Olivier, L., 2010. Nouvelles recherches sur le site de sauniers du premier Age du Fer de Marsal "La Digue" (Moselle). Antiquités nationales, 41: 127-160.

Olivier, L., Kovacik, J., 2006. The "Briquetage de la Seille": proto-industrial salt production in the European Iron Age. Antiquity, 80: 558-566.

Pany, D., Teschler-Nicola, M., 2007. Working in a salt mine: everyday life for the Hallstatt females? Lunula, 15: 89-97.

Preisig, E., 1877. Geschichte des Máramaroser Bergbaues. Oesterreichische Zeitschrift für Berg- und Hüttenwesen, 25/28-30: 301-303, 311-313, 321-323.

Riehm, K., 1962. Werkanlagen und Arbeitsgeräte urgeschichtlicher Salzsieder. Germania, 40: 360-400.

Weller, O., Dumitroaia, G., Sordoillet, D., Dufraisse, A., Gauthier, E., Munteanu, R., 2009. Lunca-Poiana Slatinei (jud. Neamt): cel mai vechi sit de exploatare a sării din preistoria europeană. Arheologia Moldovei, 32: 21-39. 